\title{
Entrepreneurial behaviour: The effects of the fear and anxiety of Covid-19 and business opportunity recognition
}

\author{
Le Thi Loan, Doung Cong Doanh, Ha Ngoc Thang, Ngo Thi Viet Nga, \\ Pham Thanh Van, Phan Thanh Hoa
}

\begin{abstract}
A B S T R A C T
Objective: The major objectives of the article were to explore the effects of the fear and anxiety of Covid-19 and business opportunity recognition on start-up self-efficacy, entrepreneurial intention, and behaviour, as well as to test entrepreneurial intention-behaviour association.

Research Design \& Methods: The study was performed by means of an online survey questionnaire conducted on 405 students at a Vietnamese university. The survey questionnaire was developed based on prior research. Structural equation modelling (SEM) was utilised to test the research model and hypotheses.

Findings: The results illustrated that the fear and anxiety of Covid-19 have a negative impact on start-up self-efficacy and entrepreneurial intention, while business opportunity recognition is strongly and positively correlated with entrepreneurial self-efficacy, entrepreneurial intention, and behaviour. In addition, entrepreneurial intention is found to be the most important antecedent to predict actual start-up behaviour whereas entrepreneurial intention significantly mediates the association between entrepreneurial self-efficacy and entrepreneurial behaviour.
\end{abstract}

Implications \& Recommendations: The study offers practical contributions for both universities and policymakers to foster youths' entrepreneurial activities and manage the negative outcome of Covid-19 on students' mental health.

Contribution \& Value Added: This research contributes to the entrepreneurship literature by addressing the notable gap when testing the linkages between entrepreneurial intention and behaviour. Furthermore, the finding confirms that the fear and anxiety of Covid-19 can decrease entrepreneurial self-efficacy, intention, and behaviour, while business opportunity recognition fosters entrepreneurial activities.

\begin{tabular}{|c|c|}
\hline $\begin{array}{l}\text { Article type: } \\
\text { Keywords: }\end{array}$ & $\begin{array}{l}\text { research article } \\
\text { fear and anxiety of Covid-19; business opportunity recognition; self-efficacy; entrepre- } \\
\text { neurial intention; entrepreneurial behaviour; pandemic }\end{array}$ \\
\hline JEL codes: & L26, M13 \\
\hline Received: & Accepted: 20 April 2021 \\
\hline
\end{tabular}

Suggested citation:

Loan, L.T., Doanh, D.C., Thang, H.N., Viet Nga, N.T., Van, P.T., \& Hoa, P.T. (2021). Entrepreneurial behaviour: The effects of fear and anxiety of Covid-19 and business opportunity recognition. Entrepreneurial Business and Economics Review, 9(3), 7-23. https://doi.org/10.15678/EBER.2021.090301

\section{INTRODUCTION}

For many years, business venture has been generating increasing interest as a result of its crucial influence on the national and global economy. Entrepreneurship is identified as the global practice and phenomenon because it contributes to economic growth, the maintenance of social stability and the reduction of unemployment rate (Lingappa, 2020; Zamrudi \& Yuliantu, 2020). Moreover, contemporary society continually undergoes a change. Entrepreneurship studies, accordingly, have experienced a body of changes. Almost all previous studies only focused on the antecedents of entrepreneurial intention (Krueger, Reilley, \& Carsud, 2000; Wach \& Bilan, 2021). However, the 
linkage between entrepreneurial intention and actual behaviour has not been explored yet in recent studies (Gubik \& Bartha, 2018; Mohammed, Zubairu, \& Oni, 2021; Nowiński et al., 2020), while investigating this relationship was determined as novel in the research stream to contribute to better knowledge about the process of business venture creation (Gieure et al., 2020). Indeed, Neneh (2019) stresses that such research limits our current understanding of entrepreneurial behaviours as increasing evidence indicates that not all entrepreneurial intentions are transformed into actual start-up behaviours (Shirokova, Osiyevkyy, \& Bogatyreva, 2016), especially in crisis conditions because of a disease outbreak (Giones et al., 2020; Ratten, 2020).

Recently, the spectre of the Covid-19 pandemic has been looming over the global economy (Lipkind \& Kitrar, 2021; Żak \& Garncarz, 2020). This pandemic not only results in serious impacts on the communities in the influenced regions, but it also leads to various levels of negative and profound mental health issues to both infected and uninfected people (Feng et al., 2020). Moreover, fear and anxiety are identified as unpleasant emotional experiences that result from a variety of antecedents, including the pandemic crisis (Mahmud et al., 2020). Since the current outbreak, some prior studies have illustrated fast growth of mental disorders such as fear and anxiety in uninfected healthy individuals as a result of the growing risk of the Covid-19 infection (Feng et al., 2020), strict quarantine measures, compulsory home isolation and other occurrences (Zhu et al., 2020). Over the last two decades, scholars have growingly investigated the psychological factors of nascent entrepreneurs to have better understanding of mechanisms underlying the influence of these psychological problems on entrepreneurial activities (Gorgievski et al., 2010). Nevertheless, almost all previous studies either examine the relationship between psychological disorders, such as psychiatric symptoms (Leung et al., 2020) and Attention-Deficit Hyperactivity Disorder symptoms (Yu et al., 2019), and entrepreneurship, or focus on exploring psychological distress, such as stress and anxiety about financial problems (Gorgievski et al., 2010), or general anxiety (Thompson et al., 2020) and business venture. However, there is a dearth of literature found to explore the fear and anxiety of Covid-19 on entrepreneurial activities (Hernández-Sánchez et al., 2020), while this information is really important and necessary for both scholars and practitioners (Giones et al., 2020). Kuckertz et al. (2020) also reported that the existence of many start-ups has been threatened by the lockdown measures to control the spread of the Covid-19 pandemic.

Business opportunity recognition consists of a person's capacity to realize, discover, and capture trends and new business concepts (Hassan, Saleem, Anwar, \& Hussan, 2020). It is considered one of the cognitive states concerned in the process of making entrepreneurial decisions by individuals (Krueger et al., 2000; Nowiński et al., 2020; Wach \& Bilan, 2021). Ratten (2020) states that entrepreneurial activities integrate a powerful mindset which can help our society rebound from a crisis, while the resilience is necessary to capture new business opportunities in times of the Covid-19 crisis (Kuckert et al., 2020). Several previous studies confirmed that opportunity recognition was found to have strong association with perceived behavioural control and entrepreneurial intention (e.g. Mahmood et al., 2019; Javis, 2016). Indeed, Hassan et al. (2020) reported that business opportunity recognition was positively correlated with university students' entrepreneurial intention, whereas Anwar, Thoudam, and Saleem (2021) argued that business opportunity recognition not only played the crucial role in sculpting entrepreneurial intention, but it affected indirectly through the self-efficacy mediator among 663 students. However, the correlations between business opportunity recognition and entrepreneurial behaviour were still not taken into consideration in prior studies.

The major objectives of the articles study are to explore the effects of the fear and anxiety of Covid-19 and business opportunity recognition on start-up self-efficacy, entrepreneurial intention, and behaviour, as well as to test entrepreneurial intention-behaviour association. Therefore, the present research has three detailed objectives: (i) to estimate the link between entrepreneurial intention and behaviour; (ii) to investigate the effects of the fear and anxiety of Covid-19 on entrepreneurial self-efficacy, entrepreneurial intention, and behaviour, and (iii) to examine the role of business opportunity recognition in shaping entrepreneurial self-efficacy, entrepreneurial intention, and behaviour among university students. 
This article includes five parts: Introduction, literature review, material and method, results and discussions, and conclusion.

\section{LITERATURE REVIEW}

\section{Entrepreneurship: The intention-behaviour gap}

Establishing a new enterprise is identified as a process which starts when a person develops and is driven by the intentions to involve in entrepreneurial activities and finishes when that person creates and runs an actual business (Elnadi \& Gheith, 2021). This behaviour might take numerous forms, such as self-employment or incorporating with established businesses as a partner. Briefly, entrepreneurial behaviours are related to the formation of a business venture which is opposed to being hired by others (Baharuddin \& Rahman, 2021; Neneh, 2019; Nguyen, 2020).

It is noticed that there was a lack of common definition of entrepreneurial behaviour in the literature. In this study, the construct of entrepreneurial behaviour is defined as the capacity, skills and knowledge referred to constituent dimensions of an enterprise. Such understanding and abilities enable individuals to carry out entrepreneurial actions (Gieure et al., 2020). Thus, it means that entrepreneurial behaviour is seen as the acquired capacity which can drive a nascent entrepreneur to the stage of creating a plan and endeavouring to run one's own business (Shirokova et al., 2016). Discovering oneself capable of carrying out a particular business venture actions or even being interested in entrepreneurial actions refers to demonstrating the ability to retain intentions and involve in business venture activities. In other word, stronger intentions towards engaging in a business venture can lead to stronger likelihood of performing an entrepreneurial action (Ajzen, 1991). This insight has been supported in a body of domains when intentions have been found to have significant correlation with actual behaviour in various fields (Sheeran, 2002). Many scholars have contributed to indicating the significant linkage between intentions and actual behaviour, including business venturing (Neneh, 2019). For example, a cross-cultural study from 34 countries, conducted by Shirokova et al. (2016), showed that there is a significant and positive association between entrepreneurial intention and the behaviour of students. Van Gelderen et al. (2015) reported that stronger entrepreneurial intentions resulted in ahigh rate of entrepreneurial actions which individuals engage in. Shinnar et al. (2018) employed four-year longitudinal dataset which also confirmed that there was a strong correlation between business venture intention and actual behaviour. Indeed, previous studies suggested that there was a strong correlation between intention and actual behaviour, which accounted for 0.9 to 0.96 (Nystrand \& Olsen, 2020). Nevertheless, for the entrepreneurship field, it is suggested that entrepreneurial intention can only explain around 18 to $27 \%$ of the variance of business venture behaviour (Fayolle \& Liñán, 2014). Shinnar et al. (2018) suggested that although intentions are broadly acknowledged to be a vital predictor of actual behaviour, the linkage between entrepreneurial intentions and actual behaviour has not been adequately tested in entrepreneurship literature.

It is necessary for further research which estimates the association between intention and behaviour to create a business venture in various contexts (Neneh, 2019; Doanh, 2021a; Fauzi, Martin, \& Ravesanga, 2021). Thus, the following hypothesis is proposed to examine the entrepreneurial intention-behaviour relationship in the context of Vietnam.

H1: Entrepreneurial intention is positively associated with entrepreneurial behaviour.

In addition, self-efficacy is determined to be a central construct in the social learning theory proposed by Bandura (1977). The fundamental proposition of the social learning theory concerns people's beliefs in their abilities to create desired effects with their own actions (Bandura, 1977). In entrepreneurship literature, there is increasing attention to the role of entrepreneurial self-efficacy in predicting entrepreneurial intention (Schmitt et al., 2018). Entrepreneurial self-efficacy is defined from various viewpoints (Tsai, Chang, \& Peng, 2014). Some studies define entrepreneurial self-efficacy as entrepreneurs' self-confidence in carrying out specific actions (Shahab et al., 2019), while others depict it as people's confidence in their own abilities to perform and become successful in their entrepre- 
neurship activities (Segal, Borgia, \& Schoenfeld, 2005). Start-up self-efficacy is, therefore, a crucial precursor of intention and behaviour to engage in a business venture (Shahab et al., 2019). Indeed, prior studies confirmed that entrepreneurial self-efficacy is strongly correlated to the intention to engage in entrepreneurial activities (Elnadi \& Gheith, 2021). For instance, individuals with higher entrepreneurial self-efficacy have a higher intention to become an entrepreneur (Liñán \& Chen, 2009). Thus, the following hypothesis to estimate the entrepreneurial self-efficacy association in the context of Vietnam.

H2: Entrepreneurial self-efficacy is positively associated with entrepreneurial intention.

\section{The effect of the fear and anxiety of Covid-19}

The entrepreneurial process relates to all the activities, functions and certain actions correlated with the perceived business opportunities and the foundation of the firm to pursue these business opportunities (Keh et al., 2002). Thus, in order to understand what fosters or restrains business venture activities, it is necessary to understand these antecedents and how they influence individuals' perception, attitude and intention associated with the creation of a business organization (Krueger et al., 2000). Previous studies found that the entrepreneurial process is affected by risky, uncertain and crisis conditions (Keh et al., 2002), such as a macroeconomic crisis or a war (Amorós et al., 2019), and mental disorders (Gorgievski et al., 2010; Thompson et al., 2020). However, what is less known are the impacts of the fear and anxiety of Covid-19 on the entrepreneurial process, while others have shown that the Covid-19 pandemic is determined as a major shock affecting entrepreneurship in general (e.g. Giones et al., 2020; Liñán \& Jaén, 2020; Ratten, 2020; Szostak \& Sułkowski, 2021). Hernández-Sánchez et al. (2020) state that individuals' entrepreneurial intentions are affected by the Covid-19 pandemic via the subjective perception of a serious hazard. Also, the fear and anxiety of the Covid-19 infection can pose a threat to the minds of students who are preparing to engage the workforce (Mahmud et al., 2020).

We argue that the fear and anxiety of Covid-19 can reduce entrepreneurial self-efficacy, entrepreneurial intention, and entrepreneurial behaviour due to three main reasons. First, some studies showed that self-efficacy is negatively affected by the anxiety of Covid-19 (e.g. Xiong, 2020). Also, general fear and anxiety are determined as a culprit of the self-efficacy reduction (Arora et al., 2021). Thus, in terms of entrepreneurial manner, the fear and anxiety of Covid-19 can decrease students' entrepreneurial selfefficacy. Second, general fear and anxiety are identified as negative factors, which lessen intentions to carry out a specific action in several types of behaviour, such as travelling (Lou \& Lam, 2020), help-seeking (Calear et al., 2021), and turnover intentions (Modaresnezhad, 2020). Also, Hernández-Sánchez et al. (2020) confirmed that the perception of the Covid-19 pandemic is negatively associated with entrepreneurial intentions. Last, the entrepreneurial decision is a choice made by individuals out of the alternatives of various careers (Shepherd et al., 2015), thus, when facing the fear and anxiety of Covid-19, they can hesitate to set up their own business. Also, the identification and exploitation of business opportunities can be inhibited by negative emotions due to health problems (Shepherd et al., 2015). The following hypotheses, therefore, are formulated to test these associations.

H3: The fear and anxiety of Covid-19 is negatively associated with (a) entrepreneurial self-efficacy, (b) entrepreneurial intention, and (c) entrepreneurial behaviour.

\section{The role of business opportunity recognition}

Business opportunity recognition is a phase in which business ideas for probably profitable new ventures are realized by a person (Hassan et al., 2020). Many individuals consider the decision to engage in entrepreneurial activities when they recognize potential and feasible business opportunities (Krueger et al., 2000). Schmitt et al. (2018) also confirmed that business opportunities are primary to the establishment of a new venture, business performance, then the venture development, especially for the high level of environmental uncertainty changes. Also, recent results have confirmed that a higher degree of uncertainty has been sparked by the Covid-19 pandemic (Liñán \& Jaén, 2020; Ratten, 2020). Notably, there are numerous sources of information that helps a nascent entrepreneur recognize business opportunities (Krueger et al., 2000). Finding appropriate information, however, also plays the key role in identifying business opportunities before performing entrepreneurial activities (Mahmood et al., 2019). 
Business opportunity recognition is determined as one of the most important process in creating a business venture because it comes in rescue whenever choosing a suitable idea before performing a business venture, adapting and working with all the acquired abilities and skills (Schmitt et al., 2018), thus increasing entrepreneurial self-efficacy and start-up intention and behaviour (Hassan et al., 2020). In other words, those who have a high level of potential business opportunity recognition are more likely to run their own business, as well as show greater confidence towards engaging in entrepreneurial activities. The following hypotheses, therefore, are formulated:

H4: Business opportunities recognition is negatively associated with (a) entrepreneurial self-efficacy, (b) entrepreneurial intention, and (c) entrepreneurial behaviour.

Thus, in light of previous studies and the research gap, the following conceptual framework is proposed to explain the impacts of the fear and anxiety of Covid-19 and business opportunity recognition on entrepreneurial self-efficacy, intention, and behaviour among Vietnamese university students (Figure 1).

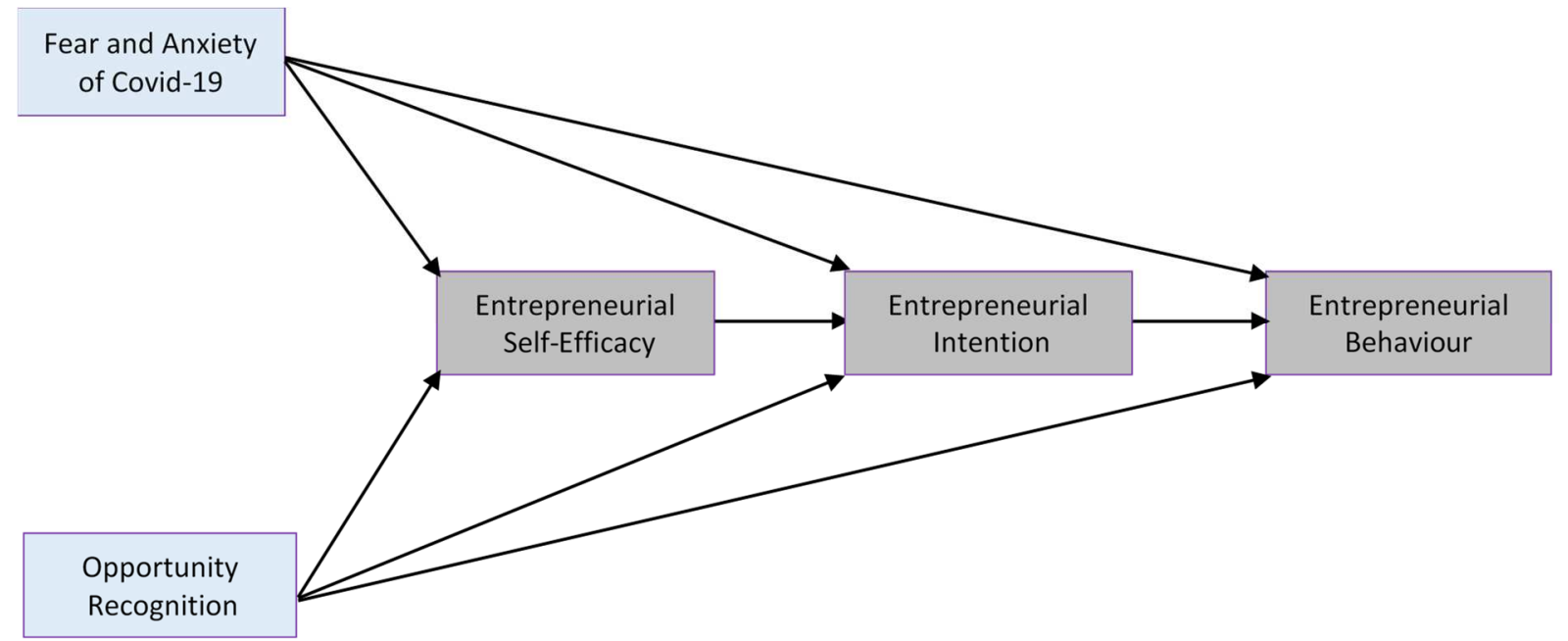

Figure 1. Conceptual Framework

Source: own elaboration.

\section{RESEARCH METHODOLOGY}

\section{Research Design and Analytical Approach}

The purpose of this study is to investigate the influence of the fear and anxiety of Covid-19, opportunity recognition, and entrepreneurial self-efficacy on entrepreneurial intention and behaviour among Vietnamese university students. Thus, the survey questionnaire is utilised to collect the dataset measuring demographic characteristics of respondents, the fear and anxiety of Covid-19, opportunity recognition, entrepreneurial self-efficacy, entrepreneurial intention and entrepreneurial behaviour. The scales (the survey items) were based on validated measurement from previous studies. The validity of scales, the conceptual framework, and the proposed hypotheses were tested using Cronbach's Alpha, Confirmatory Factor Analysis (CFA), and Structural Equation Modelling (SEM) supported by SPSS and AMOS 24.0 software.

Particularly, the Cronbach's alpha first and confirmatory factor analysis (CFA) were utilised to estimate the reliability and discriminatory value of each scales (Hair et al., 2020). Then, structure equation method (SEM) was conducted following two stages in this study and several proper analysis techniques were employed to validate the proposed model and to test the research hypotheses (Jackson, 2009; Byrne, 2010; Hair et al., 2020). Also, bootstrapping approach with the use of PROCESS version 3.5 via SPSS 24.0 was utilised to examine mediation correlations (Hayes, 2013). 


\section{Research instrument}

To measure the main constructs of this study, the study adopted the existing measures which had been validated in prior research. Specifically, the five-item measures reflecting "fear and anxiety of Covid19" was modified from Lee et al. (2020). The measures of "opportunity recognition" (five items) were adopted from Ozgen and Baron (2007). The "Entrepreneurial self-efficacy" scale with five items was adopted from Tsai, Chang, and Peng (2014). "Entrepreneurial intention" was measured by six items which were adopted from Liñán and Chen (2009). The scale of "entrepreneurial behaviour" was modified following Lortie and Castogiovanni (2015). A five-point Likert scale was employed in all items (observed variables) of the survey questionnaire, rating from 1 (strongly disagree) to 5 (strongly agree). All scales (and/or instruments) had been reliably and discriminatively validated by previous studies in various contexts, for example, the fear and anxiety of Covid-19 (Doanh, 2021b), opportunity recognition (Hassan et al., 2020), entrepreneurial self-efficacy (Shahab et al., 2019), entrepreneurial intention and behaviour (Gieure et al., 2020). Before delivering the survey questionnaire, 20 students from National Economics University, Thuongmai University and Hanoi University of Science and Technology were invited to voluntarily participate in the survey. The initial survey helps us correct several errors and guarantees that respondents understand the questions correctly.

\section{Sampling and data collection}

The online-based cross-sectional survey questionnaire with the tool of Google docs was conducted from 20th September to 20th October 2020 at Vietnamese universities. Despite physical distancing measures were permitted to relax at that time in almost all cities in Vietnam, some other measures, including face masks, staying at least 2 metres away, closing unnecessary services (karaoke, games, bars...) were set by the authorities. The tool of online dataset collection, thus, was employed to be safer during the Covid-19 pandemic. All the students were clearly apprised that answering the survey questionnaire was not compulsory, it was completely voluntary to take part in it. The personal information of respondents was kept in strict confidence and only used for the research.

Initially, the study collected 429 responses. Nevertheless, 24 responses were eliminated because of being not completely fulfilled (missing values). Finally, the sample of 405 undergraduate students from different Vietnamese universities was utilised for analyses. The samples were randomly selected and described in Table 1. Holmes (1983) argued that at least 115 valid answers for the totality of the sample size are necessary to guarantee that this sample is effective for further analyses, especially for studies related to psychological variables. Thus, the sample of 405 responses is effective for further analysis.

Table 1. Personal characteristics of respondents

\begin{tabular}{|l|l|r|r|}
\hline \multicolumn{1}{|c|}{ Variables } & \multicolumn{1}{|c|}{ Characteristics } & Frequency & $\%$ \\
\hline \multirow{3}{*}{ Gender } & Male & 159 & 39.3 \\
\cline { 2 - 4 } & Female & 246 & 60.7 \\
\hline \multirow{4}{*}{ Age } & From 18 to 20 years old & 227 & 68.4 \\
\cline { 2 - 4 } & From 21 to 23 years old & 93 & 23.0 \\
\cline { 2 - 4 } & Over 23 years old & 258 & 8.6 \\
\hline \multirow{3}{*}{ Fields of study } & Economics and Business Management & 147 & 36.3 \\
\cline { 2 - 4 } & Engineering and others & 75 & 18.5 \\
\hline \multirow{4}{*}{ Years of study } & $1^{\text {st }}$ year & 135 & 33.3 \\
\cline { 2 - 4 } & $2^{\text {nd }}$ year & 132 & 32.6 \\
\cline { 2 - 4 } & $3^{\text {rd }}$ year & 63 & 15.6 \\
\cline { 2 - 4 } & Final year & \multicolumn{2}{c|}{} \\
\hline
\end{tabular}

Source: own calculations ( $N=405)$. 


\section{RESULTS AND DISCUSSION}

\section{The measurement model}

Confirmatory factor analysis and Cronbach's alpha were used to test the reliabilities and validities of the scales. However, the fit indices of the initial measurement model were not within the recommended degree (Hair et al., 2020). Jackson (2009) suggested that all unsuitable items (low factor loading) should be extracted from the measurement model. Thus, three items, including FAC1 ("I felt dizzy, lightheaded, or faint when I read or listened to the news about the coronavirus", $\lambda=0.418$ ), ESE2 ("I show great aptitude for leadership and problem-solving", $\lambda=0.491$ ) and EB6 ("I can save money to invest in a business", $\lambda=0.489$ ), were removed because their factor loadings were lower than 0.5 . In addition, according to Jackson (2009), if the value of MI (Modification Indices) is higher than 15, it means that there are redundancies in the measurement model. Therefore, all these redundant items scales are connected to increase the model fit. Figure 2 depicts the final measurement model with recommended fit indexes. TLI and CFI were higher than 0.9, whereas NFI and GFI were over 0.8. Besides, Chi-Square/df < 3, while RMSEA is lower than 0.06 (Jackson, 2009).

Table 2 illustrates the final results of Cronbach's alpha values, average variance extracted (AVE), composite reliability (CR) of all the concepts, and factor loading (standardised regression weights) of each item after extracting inappropriate items. The results demonstrate that all the scales were found to reach satisfactory values with the smallest degree of 0.696 ( $\left.\alpha_{\mathrm{ESE}}=0.696\right)$, thus, the internal consistency reliabilities of all the variables were reached (Hair et al., 2020). Also, CR values for all the variables were found to be around or higher than 0.7, although AVE values of "fear and anxiety of Covid-19", "business opportunity recognition", "entrepreneurial self-efficacy" and "entrepreneurial intention" accounted only for $0.368,0.334,0.391$ and 0.391 respectively, these values could be satisfactory if their CR values were higher than 0.6 (e.g. Ertz et al., 2016; Lam, 2012). Thus, the scales showed the discriminant validity and construct reliability.

\section{The structural model}

The result of the structural equation analysis was depicted in Figure 3, while Table 3 summarised the outcome of testing hypotheses. The results showed that the proposed model fitted well. While GFI and NIF illustrated a value higher than 0.8, the TLI and CFI demonstrated a value of over 0.9. ChiSquare/df was lower than 0.3, whereas RMSEA was lower than 0.08 (Jackson, 2009). The variance explained $\left(R^{2}\right)$ of ESE, El and EB were $0.398,0.663$, and 0.700 , respectively. These indicated the evidence that the model showed considerable insights regarding the antecedents of entrepreneurial intention and entrepreneurial behaviour, both direct and indirect effects.

The result of the proposed hypotheses was depicted in Table 3. The result of the structural path analysis provided supports for seven of the eight hypotheses. Specifically, the result confirmed that $\mathrm{H} 1$ proposed a significant association between entrepreneurial intention and entrepreneurial behaviour $(\beta=0.590 ; p<0.001)$ and it was supported by the dataset. This result goes beyond all previous expectations (e.g. Fayolle \& Liñán, 2014; Shirokova et al., 2016). Therefore, the present study provides contributions to broader entrepreneurship literature on the notable gap between entrepreneurial intention and actual behaviour in general, which was proposed in several prior studies (e.g. Fayolle \& Liñán, 2014). Entrepreneurial self-efficacy was found to have strong effect on entrepreneurial intention $(\beta=0.501 ; p<0.001)$. $\mathrm{H} 2$, therefore, was supported. This finding was consistent with previous studies (Tsai et al., 2014; Shahab et al., 2019).

Interestingly, the fear and anxiety of Covid-19 was negatively correlated with entrepreneurial self-efficacy $(\beta=-0.184 ; p=0.039<0.05)$ and entrepreneurial intention $(\beta=-0.397 ; p<0.01)$. However, the fear and anxiety of Covid-19 was not found to have a linkage with entrepreneurial behaviour $(p>0.05)$. Thus, $\mathrm{H} 3 \mathrm{a}, \mathrm{H} 3 \mathrm{~b}$ were supported, while $\mathrm{H} 3 \mathrm{c}$ was not. The findings reveal that the fear and anxiety of Covid-19 decrease entrepreneurial self-efficacy and entrepreneurial intention. Indeed, individuals can hesitate to start a business venture at present because they are afraid 
to be inflected by Covid-19 (Dubey et al., 2020). These relationships were proposed in some previous qualitative research (Giones et al., 2020; Liñán \& Jaén, 2020), but still has not been statistically examined. However, the correlation between the fear and anxiety of Covid-19 and entrepreneurial behaviour was not statistically proven in this study.

Besides, business opportunity recognition had significant impact on entrepreneurial self-efficacy $(\beta=0.685 ; p<0.001)$, entrepreneurial intention $(\beta=0.599 ; p<0.001)$, and entrepreneurial behaviour $(\beta=0.553 ; p<0.001)$. $\mathrm{H} 4 \mathrm{a}, \mathrm{H} 4 \mathrm{~b}$ and $\mathrm{H} 4 \mathrm{c}$, therefore, were supported by the data. Several prior studies also confirmed the relationship between business opportunity recognition and entrepreneurial intention (e.g. Hassan et al., 2020), however, according to our best knowledge, the study is

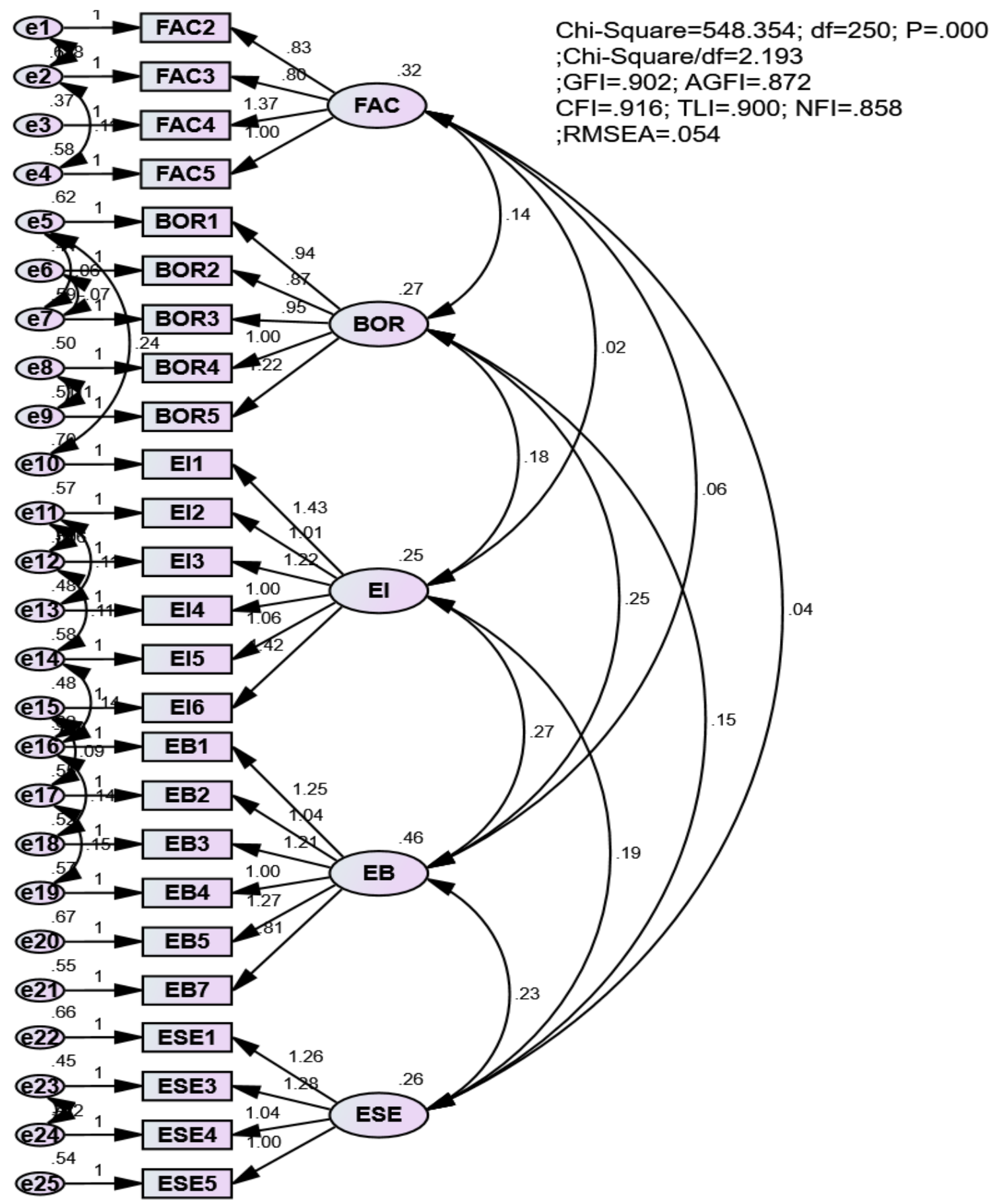

Figure 2. The measurement model

Source: own elaboration. 
Table 2. Cronbach's alpha and Confirmatory Factor Analysis report summary

\begin{tabular}{|c|c|c|c|c|c|}
\hline Code & Variables & $\lambda$ & $\begin{array}{c}\text { Cronbach's } \\
\text { Alpha }\end{array}$ & CR & AVE \\
\hline FAC & Fear and anxiety of Covid-19 (Lee et al., 2020) & & 0.740 & 0.691 & 0.368 \\
\hline FAC2 & I had trouble falling or staying asleep because I was thinking about the coronavirus & 0.501 & 0.700 & & \\
\hline FAC3 & I felt paralysed or frozen when I thought about or was exposed to information about the coronavirus & 0.503 & 0.661 & & \\
\hline FAC4 & I lost interest in eating when I thought about or was exposed to information about the coronavirus & 0.788 & 0.685 & & \\
\hline FAC5 & I felt nauseous or had stomach problems when I thought about or was exposed to information about the coronavirus & 0.600 & 0.677 & & \\
\hline BOR & Business opportunity recognition (Ozgen \& Baron, 2007) & & 0.724 & 0.714 & 0.334 \\
\hline BOR1 & I see many opportunities to start and grow a business & 0.526 & 0.693 & & \\
\hline BOR2 & Finding potential venture opportunities is easy for me & 0.562 & 0.692 & & \\
\hline BOR3 & In general, there are many opportunities for new product innovation & 0.541 & 0.694 & & \\
\hline BOR4 & I have a special sense of new venture ideas & 0.590 & 0.653 & & \\
\hline BOR5 & During my routine day-to-day activities, I see potential new venture ideas & 0.662 & 0.650 & & \\
\hline ESE & Entrepreneurial self-efficacy (Liñán, 2008; Tsai, Chang, \& Peng, 2014) & & 0.696 & 0.718 & 0.391 \\
\hline ESE1 & I show great aptitude for creativity and innovation & 0.618 & 0.606 & & \\
\hline ESE3 & I can develop and maintain favourable relationships with potential investors & 0.696 & 0.615 & & \\
\hline ESE4 & I can see new market opportunities for new products and services & 0.610 & 0.672 & & \\
\hline ESE5 & I can develop a working environment that encourages people to try out something new & 0.569 & 0.627 & & \\
\hline El & Entrepreneurial Intention (Liñán \& Chen, 2009) & & 0.803 & 0.792 & 0.391 \\
\hline El1 & I am ready to do anything to be an entrepreneur & 0.651 & 0.778 & & \\
\hline EI2 & My professional goal is to become an entrepreneur & 0.558 & 0.781 & & \\
\hline EI3 & I will make every effort to start and run my own firm & 0.652 & 0.765 & & \\
\hline EI4 & I am determined to create a firm in the future & 0.586 & 0.775 & & \\
\hline EI5 & I have a very seriously through of starting a firm & 0.572 & 0.780 & & \\
\hline El6 & I have the firm intention to start a firm some day & 0.717 & 0.756 & & \\
\hline EB & Entrepreneurial Behaviour (Gieure et al., 2020) & & 0.855 & 0.848 & 0.483 \\
\hline EB1 & I have experience in starting new projects or businesses & 0.732 & 0.825 & & \\
\hline EB2 & I am capable of developing a business plan & 0.689 & 0.829 & & \\
\hline EB3 & I know how to start a new business & 0.751 & 0.819 & & \\
\hline EB4 & I know how to do market research & 0.667 & 0.830 & & \\
\hline EB5 & I have invested in an informal manner in some business & 0.725 & 0.826 & & \\
\hline EB7 & I belong to a social network that can promote my business & 0.595 & 0.851 & & \\
\hline
\end{tabular}

Note: $\lambda=$ factor loading (standardized regression weights).

Source: own calculations $(\mathrm{N}=405)$. 


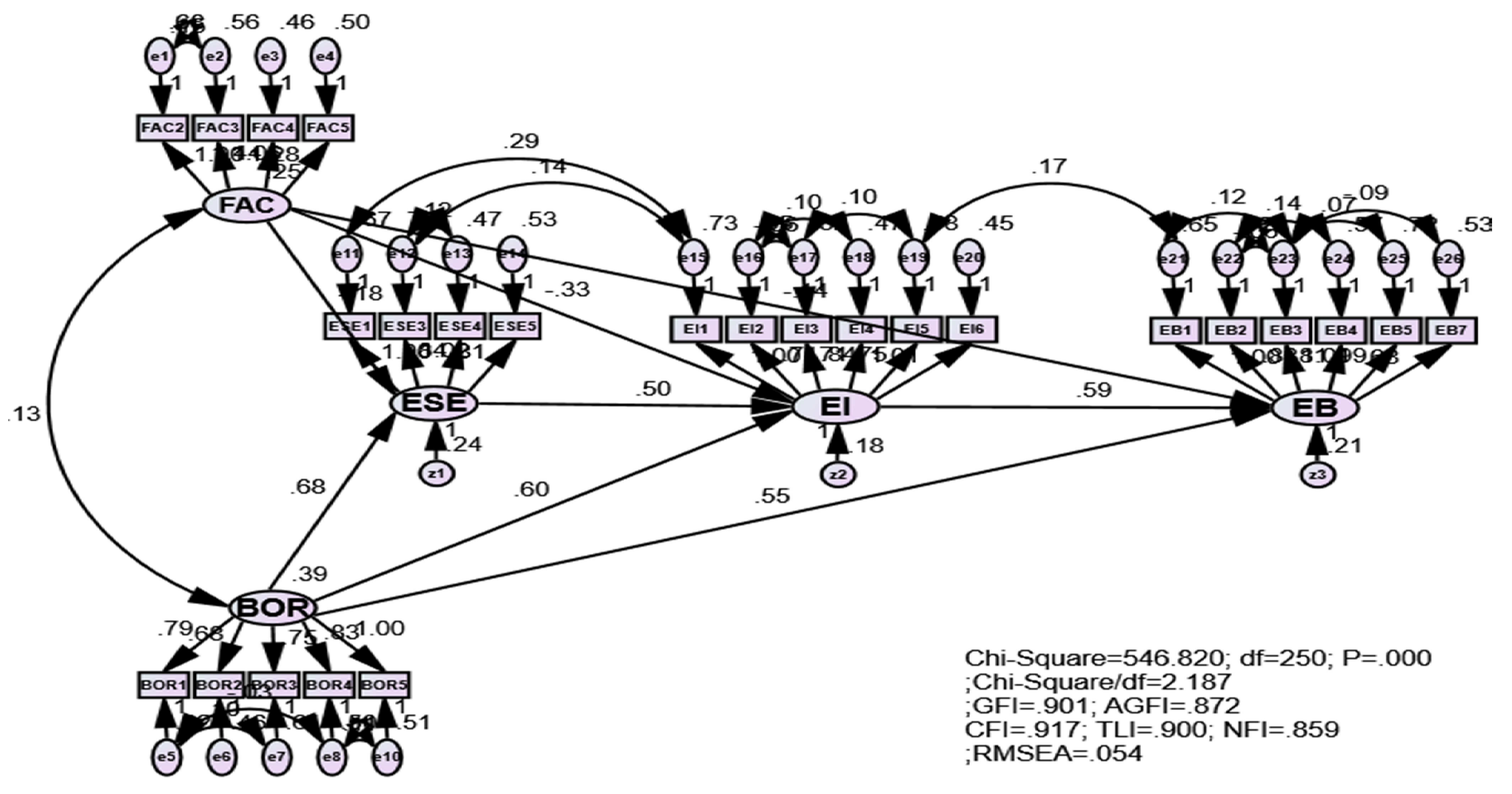

Figure 3. The structural model

Source: own elaboration. 
the first to reveal that business opportunity recognition helps individuals increase their entrepreneurial self-efficacy and foster actual entrepreneurial behaviour. Indeed, while Hassan et al. (2020) only considered the impact of opportunity recognition on entrepreneurial intention, Mahmood et al. (2019) examined the role of opportunity recognition in shaping perceived control behaviour, then translated into intention and behaviour to engage in business venture among Asnaf Millennials.

Table 3. The result of testing hypotheses

\begin{tabular}{|c|c|c|c|c|c|c|c|c|}
\hline \multicolumn{4}{|c|}{ Hypotheses } & \multirow{2}{*}{$\begin{array}{c}\text { Estimate } \\
0.590\end{array}$} & \multirow{2}{*}{$\begin{array}{c}\text { S.E. } \\
0.116\end{array}$} & \multirow{2}{*}{$\begin{array}{c}\text { C.R. } \\
5.099\end{array}$} & \multirow{2}{*}{$\frac{\text { P-value }}{* * *}$} & \multirow{2}{*}{$\frac{\text { Result }}{\text { Supported }}$} \\
\hline H1 & $\mathrm{EI}$ & $\rightarrow$ & EB & & & & & \\
\hline $\mathrm{H} 2$ & ESE & $\rightarrow$ & $\mathrm{El}$ & 0.501 & 0.101 & 4.985 & $* * *$ & Supported \\
\hline H3a & FAC & $\rightarrow$ & ESE & -0.184 & 0.097 & -1.890 & 0.039 & Supported \\
\hline H3b & FAC & $\rightarrow$ & $\mathrm{El}$ & -0.327 & 0.101 & -3.239 & 0.001 & Supported \\
\hline H3c & FAC & $\rightarrow$ & $E B$ & -0.141 & 0.114 & -1.231 & 0.218 & Not supported \\
\hline $\mathrm{H} 4 \mathrm{a}$ & BOR & $\rightarrow$ & ESE & 0.685 & 0.102 & 6.686 & $* * *$ & Supported \\
\hline H4b & BOR & $\rightarrow$ & $\mathrm{El}$ & 0.599 & 0.123 & 4.872 & $* * *$ & Supported \\
\hline H4c & BOR & $\rightarrow$ & EB & 0.553 & 0.156 & 3.541 & $* * *$ & Supported \\
\hline
\end{tabular}

Note: ${ }^{* * *} p<0.001$

Source: own calculations ( $\mathrm{N}=405)$.

Moreover, the bootstrapping method (5000 bootstrapping sample and $95 \%$ confidence interval) was employed in our study to estimate mediation associations (Cheung \& Lau, 2008). The result showed that the fear and anxiety of Covid-19 was not found to have indirect effects on entrepreneurial intention and entrepreneurial behaviour through entrepreneurial self-efficacy and entrepreneurial intention $(p>$ $0.05)$, respectively, while business opportunity recognition had indirect impact on entrepreneurial intention via entrepreneurial self-efficacy $(\beta=0.2232 ; p<0.05)$ and entrepreneurial behaviour via entrepreneurial intention $(\beta=0.3255 ; p<0.05)$. The correlation between entrepreneurial self-efficacy and entrepreneurial behaviour was also mediated by entrepreneurial intention $(\beta=0.3427 ; p<0.05)$.

Table 4. The result of mediation associations

\begin{tabular}{|c|c|c|c|c|c|c|c|c|}
\hline \multirow{2}{*}{\multicolumn{5}{|c|}{ Mediation paths }} & \multirow{3}{*}{$\begin{array}{c}\begin{array}{c}\text { Indirect } \\
\text { effects }\end{array} \\
0.0443\end{array}$} & \multirow{3}{*}{$\begin{array}{c}\text { SE } \\
0.0307\end{array}$} & \multicolumn{2}{|c|}{$95 \%$ confidence interva } \\
\hline & & & & & & & \multirow{2}{*}{$\begin{array}{c}\text { LLCI } \\
-0.0148\end{array}$} & \multirow{2}{*}{$\begin{array}{c}\text { ULCI } \\
0.1068 \\
\end{array}$} \\
\hline FAC & $\rightarrow$ & ESE & $\rightarrow$ & $\mathrm{El}$ & & & & \\
\hline FAC & $\rightarrow$ & $\mathrm{EI}$ & $\rightarrow$ & EB & 0.0133 & 0.0355 & -0.0559 & 0.0821 \\
\hline BOR & $\rightarrow$ & ESE & $\rightarrow$ & $\mathrm{El}$ & $0.2232^{*}$ & 0.0314 & 0.1653 & 0.2881 \\
\hline BOR & $\rightarrow$ & $\mathrm{El}$ & $\rightarrow$ & $E B$ & $0.3255^{*}$ & 0.0367 & 0.2546 & 0.4006 \\
\hline ESE & $\rightarrow$ & $\mathrm{El}$ & $\rightarrow$ & EB & $0.3427^{*}$ & 0.0428 & 0.2621 & 0.4292 \\
\hline
\end{tabular}

Note: ${ }^{*} p<0.05$

LLCI: Lower level of confidence interval. ULCI: Upper level of confidence interval. SE: Standard errors.

Source: own calculations.

\section{CONCLUSIONS}

The aim of this study was to estimate the influence of the fear and anxiety of Covid-19 and business opportunity recognition on entrepreneurial self-efficacy, intention, and behaviour among Vietnamese students, as well as to fulfil the research gap in exploring the entrepreneurial intention-behaviour association.

The study provides several theoretical contributions to entrepreneurship literature. Firstly, this study filled the intention-behaviour gap in entrepreneurship. Secondly, the research showed that entrepreneurial self-efficacy directly affects entrepreneurial intention, then transferred into entrepreneurial behaviour through entrepreneurial intention. Thirdly, the study revealed that the fear and anxiety of Covid-19 have decreased entrepreneurial self-efficacy and intention to start one's own business. Finally, business opportunity recognition was found to have significant impact on entrepreneurial self-efficacy, intention, and behaviour. 
The research offers practical applications for both universities and policymakers. First, in order to promote entrepreneurial activity, the Vietnamese government should have the appropriate policies to increase entrepreneurial self-efficacy of the youth and help them recognize business opportunity through educational programmes and institutional solutions. Simultaneously, entrepreneurship should be included in the curriculum design with the activity-based teaching method at universities to help students enhance entrepreneurial knowledge, skills, capacity, and self-efficacy. This can increase students' intention and actual behaviour of engaging in entrepreneurial career (Tsai et al., 2014). Second, for controlling the negative influence of the Covid-19 pandemic on entrepreneurial activities, although the coronavirus outbreak has been well-managed in Vietnam, the government and universities should take into account students' mental health problems which are derived from the lockdown, physical distancing, school closure measures. Particularly, universities can reduce students' pressure and stress related to exams during the Covid-19 pandemic. The reduction of difficulty level of final exams or using E-exams should be employed during the Covid-19 pandemic (Elsalem et al., 2020).

However, we also acknowledge that this research can have several limitations that can help further studies. First, this study only focuses on the effects of the fear and anxiety of Covid-19, business opportunity recognition on entrepreneurial self-efficacy, entrepreneurial intention and behaviour, future research should expand the conceptual model by considering the impacts of personal and context factors (Wach \& Głodowska, 2021). Second, the present study indicates that the fear and anxiety of Covid-19 are not associated with entrepreneurial behaviour, later studies should test this linkage further in a different context. Lastly, this study only tests the direct effect of the fear and anxiety of Covid-19 on entrepreneurship, while the coronavirus affects almost all perspectives of our life, further research into the influence of the Covid-19 pandemic should be conducted in order to control this disease better.

\section{REFERENCES}

Ajzen, I. (1991). The theory of planned behaviour. Organizational Behaviour and Human Decision Processes, 50(2), 179-211. https://doi.org/10.1016/0749-5978(91)90020-T

Anwar, I., Thoudam, P., \& Saleem, I. (2021). Role of entrepreneurial education in shaping entrepreneurial intention among university students: Testing the hypotheses using mediation and moderation approach. Journal of Education for Business, https://doi.org/10.1080/08832323.2021.1883502

Arora, S., Chaudhary, P., \& Singh, R.K. (2021). Impact of coronavirus and online exam anxiety on self-efficacy: the moderating role of coping strategy. Interactive Technology and Smart Education, 1741-5659. https://doi.org/10.1108/ITSE-08-2020-0158

Amorós, J.E., Ciravegna, L., Mandakovic, V., \& Stenholm, P. (2019). Necessity or Opportunity? The Effects of State Fragility and Economic Development on Entrepreneurial Efforts. Entrepreneurship Theory and Practices, 43(4), 725-750. https://doi.org/10.1177/1042258717736857

Baharuddin, G., \& Ab Rahman, A. (2021). What is the most effective antecedent for developing entrepreneurial intention among Muslim youth in Indonesia?. Entrepreneurial Business and Economics Review, 9(1), 75-88. https://doi.org/10.15678/EBER.2021.090105

Bandura, A. (1977). Social Learning Theory. Englewood Cliffs, NJ: Prentice Hall.

Byrne, B. (2010). Structural equation modelling with AMOS: Basic concepts, applications and programming (6th ed.). New York, USA: Taylor \& Francis Group.

Calear, A.L., Batterham, P.J., Torok, M., \& McCallum, S. (2021). Help-seeking attitudes and intentions for generalised anxiety disorder in adolescents: the role of anxiety literacy and stigma. European Child \& Adolescent Psychiatry, 30(2), 243-251. https://doi.org/10.1007/s00787-020-01512-9

Cheung, G.W., \& Lau, R.S. (2008). Testing Mediation and Suppression Effects of Latent Variables: Bootstrapping with Structural Equation Models. Organizational Research Methods, 11(2), 296-325. https://doi.org/10.1177/1094428107300343

Doanh, D.C. (2021a). The role of contextual factors on predicting entrepreneurial intention among Vietnamese students. Entrepreneurial Business and Economics Review, 9(1), 169-188. https://doi.org/10.15678/EBER.2021.090111 
Doanh, D.C. (2021b). The impact of fear and anxiety of covid-19 on life satisfaction: Psychological distress and sleep disturbance as mediators. Personality and Individual Differences, 178, 110869. https://doi.org/10.1016/j.paid.2021.110869

Dubey, S., Biswas, P., Ghosh, R., Chatterjee, S., Dubey, M.J., Chatterjee, S., Lahiri, D., \& Lavie, C.J. (2020). Psychosocial impact of COVID-19. Diabetes \& Metabolic Syndrome, 14(5), 779-788. https://doi.org/10.1016/j.dsx.2020.05.035

Elnadi, M., \& Gheith, M. (2021). Entrepreneurial ecosystem, entrepreneurial self-efficacy, and entrepreneurial intention in higher education: Evidence from Saudi Arabia. The International Journal of Management Education, 100458. https://doi.org/10.1016/j.ijme.2021.100458

Ertz, M., Karakas, F., \& Sarigöllü, E. (2016). Exploring pro-environmental behaviours of consumers: An analysis of contextual factors, attitude, and behaviours. Journal of Business Research, 69, 3971-3980. https://doi.org/10.1016/j.jbusres.2016.06.010

Fayolle, A., \& Liñán, F. (2014). The future of research on entrepreneurial intentions. Journal of Business Research, 67(5), 663-666. https://doi.org/110.1016/j.jbusres.2013.11.024

Elsalem, L., Al-Azzam, N., Jumah, A., Obeidat, N., Sindiani, A.M., \& Kheirallah, K.A. (2020). Stress and behavioural changes with remote E-exams during the Covid-19 pandemic: A cross-sectional study among undergraduates of medical sciences. Annals of Medicine and Surgency, 40, 271-279. https://doi.org/10.1016/j.amsu.2020.10.058

Fauzi, M.A., Martin, T., \& Ravesangar, K. (2021). The influence of transformational leadership on Malaysian students' entrepreneurial behaviour. Entrepreneurial Business and Economics Review, 9(1), 89-103. https://doi.org/10.15678/EBER.2021.090106

Feng, L., Dong, Z., Yan, R., Wu, X., Ma, J., \& Zeng, Y. (2020). Psychological distress in the shadow of the Covid-19 pandemic: Preliminary development of an assessment scale. Psychiatry Research, 291, 113202. https://doi.org/10.1016/j.psychres.2020.113202

Gieure, C., Benavides-Espinosa, M.M., \& Roig-Bobón, S. (2020). The entrepreneurial process: The link between intentions and behaviour. Journal of Business Research, 112, 541-548. https://doi.org/10.1016/j.jbusres.2019.11.088

Giones, F., Brem, A., Pollack, J.M., Michaelis, T.L., Klyver, K., \& Brinckmann, J. (2020). Revising entrepreneurial action in response to exogenous shocks: Considering the COVID-19 pandemic. Journal of Business Venturing Insights, 14, e.00186. https://doi.org/10.1016/j.jbvi.2020.e00186

Gorgievski, M.J., Bakker, A.B., Schaufeli, W.B., van der Veen, H.B., \& Giesen, C.W.M. (2010). Financial problems and psychological distress: Investigating reciprocal effects among business owners. Journal of Occupational and Organizational Psychology, 83, 513-530. https://doi.org/10.1348/096317909X434032

Gubik, A.S., \& Bartha, Z. (2018). The role of university in influencing the entrepreneurial intention of university students. International Entrepreneurship Review, 4(3), 177-188.

Hair, J.F., Howard, M.C., \& Nitzl, C. (2020). Assessing measurement model quality in PLS-SEM using confirmatory composite analysis. Journal of Business Research, 109, 101-110. https://doi.org/10.1016/j.jbusres.2019.11.069

Hassan, A., Saleem, I., Anwar, I., \& Hussain, S.A. (2020). Entrepreneurial intention of Indian university students: the role of opportunity recognition and entrepreneurship education. Education + Training, 62(7/8), 843-861. https://doi.org/10.1108/ET-02-2020-0033

Hayes, A.F. (2013). Methodology in the social sciences: Introduction to mediation, moderation, and conditional process analysis: A regression-based approach. Guilford Press.

Hernández-Sánchez, B.R., Cardella, G.M., \& Sánchez-García, J.C. (2020). Psychological Factors that Lessen the Impact of COVID-19 on the Self-Employment Intention of Business Administration and Economics' Students from Latin America. International Journal of Environmental Research and Public Health, 17, 5293. https://doi.org/10.3390/ijerph17155293

Holmes, C. (1983). Sample Size in Four Areas of Psychological Research. Transactions of the Kansas Academy of Science, 86(2/3), 76-80. https://doi.org/10.2307/3627914

Jackson, D.L. (2009). Revisiting sample size and number of parameter estimates: some support for the N: q hypothesis. Structural Equation Modelling, 10(1), 128-141. https://doi.org/10.1207/S15328007SEM1001_6

Keh, H.T., Foo, M.D., \& Lim, B.C. (2002). Opportunity evaluation under risky conditions: The cognitive processes of entrepreneurs. Entrepreneurship Theory and Practice, 27(2), 125-148. https://doi.org/10.1111/1540-8520.00003

Krueger, N.F., Jr., Reilly, M.D., \& Carsrud, A.L. (2000). Competing models of entrepreneurial intentions. Journal of Business Venturing, 15(5-6), 411-432. https://doi.org/10.1016/S0883-9026(98)00033-0 
Kuckertz, A., Brändle, L., Gaudig, A., Hinderer, S., Morales Reyes, C.A., Prochotta, A., Steinbrink, K.M., \& Berger, E.S.C. (2020). Startups in times of crisis - a rapid response to the COVID-19 pandemic. Journal of Business Venturing Insights, 13, e00169. https://doi.org/10.1016/j.jbvi.2020.e00169

Lam, L.W. (2012). Impact of competitiveness on salespeople's commitment and performance. Journal of Business Research, 65(9), 1328-1334. https://doi.org/10.1016/j.jbusres.2011.10.026

Lee, S.A., Mathis, A.A., Jobe, M.C., \& Pappalardo, E.A. (2020). Clinically significant fear and anxiety of Covid-19: A psychometric examination of the Coronavirus Anxiety Scale. Psychiatry Research, 290, 112112. https://doi.org/10.1016/j.psychres.2020.113112

Leung, Y.K., Franken, I.H.A., \& Thurik, A.R. (2020). Psychiatric symptoms and entrepreneurial intention: The role of the behavioural activation system. Journal of Business Venturing Insights, 13, 1-10. https://doi.org/10.1016/j.jbvi.2019.e00153

Lingappa, A.K., Shah, A., \& Mathew, A.O. (2020). Academic, Family, and Peer Influence on Entrepreneurial Intention of Engineering Students. Sage Open, 1-12, https://doi.org/10.1177/2158244020933877

Liñán, F., \& Jaén, I. (2020). The Covid-19 pandemic and entrepreneurship: some reflections. International Journal of Emerging Markets. https://doi.org/10.1108/IJOEM-05-2020-0491

Liñán, F., \& Chen, Y.W. (2009). Development and cross-cultural application of a specific instrument to measure entrepreneurial intentions. Entrepreneurship Theory and Practice, 33, 593-617. https://doi.org/10.1111/j.1540-6520.2009.00318.x

Lipkind, T., \& Kitrar, L. (2021). The relationship of economic sentiment and GDP growth in Russia in light of the Covid-19 crisis?. Entrepreneurial Business and Economics Review, 9(1), 7-29. https://doi.org/10.15678/EBER.2021.090101

Lortie, J., \& Castogiovanni, G. (2015). The theory of planned behaviour in entrepreneurship research: What we know and future directions. International Entrepreneurship and Management Journal, 11(4), 935-957. https://doi.org/10.1007/s11365-015-0358-3

Lou, J.M., \& Lam, C.F. (2020). Travel Anxiety, Risk Attitude and Travel Intentions towards "Travel Bubble" Destinations in Hong Kong: Effect of the Fear of COVID-19. International Journal of Environmental Research and Public Health, 17(21), 7859. https://doi.org/10.3390/ijerph17217859

Mohammed, A., Zubairu, U.M., \& Oni, E.O. (2021). Public entrepreneurship literature from 2010 to 2019: A systematic review. International Entrepreneurship Review, 7(1), 45-58. https://doi.org/10.15678/IER.2021.0701.04

Mahmud, M.S., Talukder, M.U., \& Rahman, S.M. (2020). Does “fear of covid-19' trigger future career anxiety? An empirical investigation considering depression from Covid-19 as a mediator. International Journal of Social Psychiatry, 1-11, https://doi.org/10.1177/0020764020935488

Mahmood, T.M.A.T., Mamun, A.A., Ahmad, G.B., \& Ibrahim, M.D. (2019). Predicting entrepreneurial intentions and pre-start-up behaviour among Asnaf millennials. Sustainability, 11, 4939. https://doi.org/10.3390/su11184939

Modaresnezhad, M., Andrews, M., Mesmer-Magnus, J., Viswesvaran, C., \& Deshpande, S. (2021). Anxiety, job satisfaction, supervisor support and turnover intentions of mid-career nurses: A structural equation model analysis. Journal of Nursing Management. https://doi.org/10.1111/jonm.13229

Neneh, B.N. (2019). From entrepreneurial intention to behaviour: The role of anticipated regret and proactive personality. Journal of Vocational Behaviour, 112, 311-324. https://doi.org/10.1016/j.jvb.2019.04.005

Nguyen, T. (2020). The impact of access to finance and environmental factors on entrepreneurial intention: The mediator role of entrepreneurial behavioural control. Entrepreneurial Business and Economics Review, 8(2), 127-140. https://doi.org/10.15678/EBER.2020.080207

Nowiński, W., Haddoud, M., Wach, K., \& Schaefer, R. (2020). Perceived public support and entrepreneurship attitudes: A little reciprocity can go a long way!. Journal of Vocational Behavior, 121, 103474. https://doi.org /10.1016/j.jvb.2020.103474

Nystrand, B.T., \& Olsen, S.O. (2020). Consumers' attitudes and intentions toward consuming functional foods in Norway. Food Quality and Preference, 80, 103827. https://doi.org/10.1016/j.foodqual.2019.103827

Ozgen, E., \& Baron, R.A. (2007). Social sources of information in opportunity recognition: effects of mentors, industry networks, and professional forums. Journal of Business Venturing, 22(2), 174-192. https://doi.org/10.1016/j.jbusvent.2005.12.001 
Ratten, V. (2020). Coronavirus (Covid-19) and entrepreneurship: Changing life and work landscape. Journal of Small Business \& Entrepreneurship, 32(5), 503-516. https://doi.org/10.1080/08276331.2020.1790167

Schmitt, A., Rosing, K., Zhang, S.X., \& Leatherbee, M. (2018). A Dynamic Model of Entrepreneurial Uncertainty and Business Opportunity Identification: Exploration as a Mediator and Entrepreneurial Self-Efficacy as a Moderator. Entrepreneurship Theory and Practice, 42(6), 835-859. https://doi.org/10.1177/1042258717721482

Segal, G., Borgia, D., \& Schoenfeld, J. (2005). The motivation to become an entrepreneur. International Journal of Entrepreneurial Behaviour \& Research, 11(1), 42-57. https://doi.org/10.1108/13552550510580834

Shahab, Y., Chengang, Y., Arbizu, A.D., \& Haider, M.J. (2019). Entrepreneurial self-efficacy and intention: do entrepreneurial creativity and education matter?. International Journal of Entrepreneurial Behaviour \& Research, 25(2), 259-280. https://doi.org/10.1108/IJEBR-12-2017-0522

Sheeran, P. (2002). Intention-behaviour relations: A conceptual and empirical review. European Review of Social Psychology, 12(1), 1-36.

Shepherd, D.A., Williams, T.A., \& Patzelt, H. (2015). Thinking About Entrepreneurial Decision Making: Review and Research Agenda. Journal of Management, 41(1), 11-46. https://doi.org/10.1177/0149206314541153

Shirokova, G., Osiyevskyy, O., \& Bogatyreva, K. (2016). Exploring the intention-behaviour link in student entrepreneurship: Moderating effects of individual and environmental characteristics. European Management Journal, 34, 386-399. https://doi.org/10.1016/j.emj.2015.12.007

Shinnar, R.S., Hsu, D.K., Powell, B.C., \& Zhou, H. (2018). Entrepreneurial intentions and start-ups: Are women or men more likely to enact their intentions?. International Small Business Journal: Researching Entrepreneurship, 36(1), 60-80. https://doi.org/10.1177/0266242617704277

Szostak, M., \& Sułkowski, Ł. (2021). Identity crisis of artists during the Covid-19 pandemic and shift towards entrepreneurship. Entrepreneurial Business and Economics Review, 9(3), 87-102. https://doi.org/10.15678/EBER.2021.090306

Thompson, N.A., Gelderen, M.V., \& Keppler, L. (2020). No need to worry? Anxiety and coping in the entrepreneurship process. Frontier in Psychology, 11, 1-16. https://doi.org/10.3389/fpsyg.2020.00398

Tsai, K.H., Chang, H.C., \& Peng, C.Y. (2014). Extending the link between entrepreneurial self-efficacy and intention: A moderated mediation model. International Entrepreneurship and Management Journal, 12, 445-463. https://doi.org/10.1007/s11365-014-0351-2

Van Gelderen, M.W., Kautonen, T., \& Fink, M. (2015). From entrepreneurial intentions to actions: Self-control and action related doubt, fear, and aversion. Journal of Business Venturing, 30(5), 655-673. https://doi.org/10.1016/j.jbusvent.2015.01.003

Wach, K., \& Bilan, S. (2021). Public support and administration barriers towards entrepreneurial intentions of students in Poland. Administratie si Management Public, 36(1). https://doi.org/10.24818/amp/2021.36-04

Wach, K., \& Głodowska, A (2021). How do demographics and basic traits of an entrepreneur impact the internationalisation of firms?. Oeconomia Copernicana, 12(2).

Xiong, H., Yi, S., \& Lin, Y. (2020). The Psychological Status and Self-Efficacy of Nurses During COVID-19 Outbreak: A Cross-Sectional Survey. INQUIRY: The Journal of Health Care Organization, Provision, and Financing. https://doi.org/10.1177/0046958020957114

Yu, W., Wiklund, J., \& Pérez-Luño, A. (2021). ADHD Symptoms, Entrepreneurial Orientation (EO), and Firm Performance. Entrepreneurship Theory and Practice, 45(1), 92-117. https://doi.org/10.1177/1042258719892987

Zamrudi, Z., \& Yulianti, F. (2020). Sculpting Factors of Entrepreneurship among University Students in Indonesia. Entrepreneurial Business and Economics Review, 8(1), 33-49. https://doi.org/10.15678/EBER.2020.080102

Zhu, S., Wu, Y., Zhu, C.Y., Hong, W.C., Yu, Z.X., Chen, Z.K., Chen, Z.L., Jiang, D.G., \& Wang, Y.G. (2020). The immediate mental health impacts of the COVID-19 pandemic among people with or without quarantine managements. Brain, Behaviour, and Immunity, 87, 56-58. https://doi.org/10.1016/j.bbi.2020.04.045

Żak, M., \& Garncarz, J. (2020). Economic policy towards the challenges of the COVID-19 pandemic in selected European Union countries. International Entrepreneurship Review, 6(4), 21-34. https://doi.org/10.15678/IER.2020.0604.02 


\section{Authors}

Le Thi Loan 30\% (draft writing, revising), Duong Cong Doanh (30\%) (final writing for submitting, revising), Ha Ngoc Thang (20\%) (statistic write up), Ngo Thi Viet Nga (10\%) (statistic write up), Pham Thanh Van (5\%) (draft correction), Phan Thi Thanh Hoa (5\%) (draft correction).

\section{Le Thi Loan}

PhD Student at National Economics University, Vietnam, her research interests include entrepreneurship (social business venture) and green consumption behaviour.

Correspondence to: Le Thi Loan, PhD students, Department of General Management, Faculty of Business Management, National Economics University, 207 Giai Phong, Hanoi, Vietnam, email: leloan.neu@gmail.com ORCID (1) http://orcid.org/0000-0003-1882-2865

\section{Duong Cong Doanh}

PhD in Business Management (2019, National Economics University, Vietnam \& University of Szczecin, PolandErasmus Mundus Programme); Master of Science in Management (2016, KEDGE Business School, France); Bachelor of Business Administration (2011, National Economics University, Vietnam). His research interests include entrepreneurship, corporate social responsibility, and green consumption.

Correspondence to: Duong Cong Doanh, PhD, Department of General Management, Faculty of Business Management, National Economics University, 207 Giai Phong, Hanoi, Vietnam, e-mail: doanhdc@neu.edu.vn ORCID (1) http://orcid.org/0000-0003-4431-9761

\section{Ha Ngoc Thang}

Researcher/Lecturer at Faculty of Business Management, National Economics University, Vietnam. His research interests include entrepreneurship and shopping online.

Correspondence to: Ha Ngoc Thang, PhD, Department of General Management, Faculty of Business Management, National Economics University, 207 Giai Phong, Hanoi, Vietnam, email: hangocthang@neu.edu.vn ORCID (1) http://orcid.org/0000-0001-9812-4092

\section{Ngo Thi Viet Nga}

Researcher/Lecturer at Faculty of Business Management, National Economics University, Vietnam. Her research interests include entrepreneurship and knowledge sharing.

Correspondence to: Ngo Thi Viet Nga, PhD, Department of General Management, Faculty of Business Management, National Economics University, 207 Giai Phong, Hanoi, Vietnam, email: ngovietnga711@yahoo.com ORCID (1) http://orcid.org/0000-0003-2758-7991

\section{Pham Thanh Van}

Researcher/Lecturer at Faculty of Business Management, National Economics University, Vietnam. Her research interests include entrepreneurship and green consumption behaviour.

Correspondence to: Pham Thanh Van, Department of General Management, Faculty of Business Management, National Economics University, 207 Giai Phong, Hanoi, Vietnam, email: ptvan88@gmail.com ORCID (1) http://orcid.org/0000-0001-5210-2998

\section{Phan Thanh Hoa}

Researcher/Lecturer at Faculty of Business Management, National Economics University, Vietnam. Her research interests include entrepreneurship and organizational behaviour.

Correspondence to: Phan Thanh Hoa, PhD, Department of General Management, Faculty of Business Management, National Economics University, 207 Giai Phong, Hanoi, Vietnam, email: ptthlh@gmail.com ORCID (1) http://orcid.org/0000-0001-5984-138X

\section{Acknowledgements and Financial Disclosure}

The article came into being within the project no. 339/QD-DHKTQD, financed by National Economics University, 2020. 


\section{Conflict of Interest}

The authors declare that the research was conducted in the absence of any commercial or financial relationships that could be construed as a potential conflict of interest.

\section{Copyright and License}

This article is published under the terms of the Creative Commons

Attribution - NoDerivs (CC BY-ND 4.0) License

http://creativecommons.org/licenses/by-nd/4.0/

Published by Cracow University of Economics - Krakow, Poland 
